\title{
EFFECTS OF CHILDBEARING ON RURAL WOMEN AGRICULTURAL ACTIVITIES IN IREPODUN LOCAL GOVERNMENT AREA OF KWARA STATE, NIGERIA.
}

\author{
${ }^{*}$ Ajamu, G. J., ${ }^{1}$ Matanmi, B.M. And ${ }^{2}$ Adekoya, A.E. \\ ${ }^{1}$ Department of Agricultural Extension and Rural Development, University of Ilorin, Ilorin, Nigeria \\ 2Department of Agricultural Extension and Rural Development, University of Ibadan, Ibadan, Nigeria \\ *E-mail Address: ajamujanet@yahoo.com
}

\begin{abstract}
This study was carried out to analyze the effect of child bearing on the activities of the rural women agricultural activities in Irepodun Local Government Area of Kwara State. The study was to determine socio-economic characteristics of childbearing women involved in agricultural activities, identify agricultural activities practised by childbearing women, identify the agricultural activities that are affected by childbearing and determine the effect of childbearing on women farmers' income. A total of one hundred and twenty respondents were sampled from four randomly selected wards out of the ten wards in the study area. Interview schedule was used to collect data. The study revealed that majority $(76.7 \%)$ of respondents were between the age of $36-45$ years, $80.5 \%$ were married and $72.8 \%$ were literate and had farming experience above 10 years. Ninety-five percent of the respondents were engaged in agricultural activities as their primary and secondary occupations. The study revealed that most of the agricultural activities practised by the respondents were affected during childbearing. However majority of the respondents (72.0\%) were participating in informal saving and credit group, $63.8 \%$ of the respondent contributes below $\mathrm{N} 200$ and $36.2 \%$ contribute $\mathrm{N} 450$ and above. The study revealed that childbearing affects $42.4 \%$ of the respondent income while $57.6 \%$ are not affected by childbearing, since respondent has different source of generating income. The hypothesis showed that there is no significant relationship between selected socio economic characteristics of childbearing women and number of activities they are involved in. The study therefore recommends that Women involved in agricultural activities should be given appropriate types of technology to cater for the labour intensive agricultural activities. Childbearing women are encouraged to join or form cooperative society in order to source funds from government, NGOs as well as access credit facilities from financial institutions to boost their involvement in agricultural activities.
\end{abstract}

Keywords: Childbearing, Rural women, Agricultural activities.

\section{INTRODUCTION}

Women constitute nearly half of the adult population of Nigeria and $77 \%$ of them live in the rural area. The major occupation of rural women is agriculture and its related activities. Women contribute about three-fourth of the labour required for agricultural operations (Ramesh, 2013). Regardless of the level of development achieved by the respective economies, women play a pivotal role in agriculture and in rural development in most countries (Jean-Pierre, 2012). In the process of food production, handling and preparation of food, women play multiple roles. Therefore, women are said to be feeding the world.

The role of women in Agricultural development process has been well documented. Everywhere in the world, women have been actively involved in farming, food processing and preservation (Yusuf \& Adenegan, 2009). Women produce more than half of all the food that is grown in the world (Jean-Pierre, 2012). In Sub-Sahara Africa and the Caribbean, women produce up to $80 \%$ of basic foodstuffs. In Asia, women contribute from $50-90 \%$ of the labour for rice cultivation. And in Southeast Asia and the pacific as well as Latin America, women's home gardens represent some of the most complex agricultural systems known (Dilrukshi, Russell \& Karim, 2013). 
In developing countries, rural women provide most of the labour for farming, from soil preparation to harvest. After harvest, they are mostly responsible for operation such as storage, handling, stocking, marketing and processing. In addition to rural women's economic activities, rural women also bear primary responsibility of feeding children from gestation through weaning and throughout the critical period of growth. Work in the household is also part of women's responsibility as wives and mothers rather than occupation to be accounted for in both the household and the national economy.

However, reproductive roles and productive functions played by women are so closely linked that they cannot be considered independently (Chatterjee, 1991). These reproductive roles in one way or the other can be said to affect their agricultural activities. This can be viewed in terms of valuable time spent on child bearing by these rural women. Women in developing nations in general spend what should be their productive period on reproduction (UNFPA, 1988). (Doss (1999)), found that childbearing statuses of women affect their availability for agriculture. The perennial strength which the unique roles of childbearing ascribe biologically and socially affects women's productive potential and labour supply.

The perennial stress and unique roles of child-bearing and childcare ascribed particularly to women, biologically and socially, affect their productive potential and labour supply in Agricultural production (Okeowo \& Olujide, 2014). In most developing nations, the various ailments after childbirth can be said to limit women performance and this is further aggravated by poor state of health facilities. The health of an individual is an important factor in determining performance in any situation. Therefore, maternal morbidity as a fall out from child bearing to a large extent affects woman performance of agricultural activities. By affecting women's physical health, illness also may be detrimental to their social, emotional and economic wellbeing (agricultural activities) if they affect women ability to work or interact in their communities (Population Report, 1997). Also, the rural women combine their roles as wives, mothers, and housekeepers with their priceless tasks as farmers, farm labourers, etc. (Osondu, 2014).

World Bank, 1996 observed that consistent child bearing reduces productivity not only at household level but also in the formal and non-formal economic sector. It has been observed that pregnant and lactating women contribute significantly less income generating labour over years than other women, which was attributed to less time devoted to labour intensive activities such as farming (Baksh et al, 1994). The paper therefore determined the effect of childbearing on agricultural activities of women in Irepodun local government area of Kwara State, Nigeria. The objectives of the study are to

1. determine the socio-economic characteristics of childbearing women involved in agricultural activities;

2. identify agricultural activities practised by childbearing women;

3. identify agricultural activities that are affected by childbearing; and

4. determine the effect of childbearing on women farmers' income

\section{METHODOLOGY}

\section{Study area}

The study area is Irepodun Local Government Area (LGA) of Kwara State with headquarters in OmuAran town, which was created in 1976. The area lies in the middle belt between approximately latitude $8000^{\prime} \mathrm{N}$ and $8029^{\prime} \mathrm{N}$ and longitude $400410 \mathrm{E}$ and $500340 \mathrm{E}$. The LGA has eleven wards with a population of 196,020 (99,640 males and 96,380 females) based on our population growth rate of $2.9 \% \mathrm{pa}$. Arable crops planted include yam, grains, maize, guinea corn, cassava with cashew as a cash crop. Irepodun Local Government is the largest and oldest Local Government Area in Kwara State and was created in 1968 at the inception of the state as Igbomina/Ekiti Division. Indeed the Local Government was an offshoot of the defunct llorin Native Authority of the Colonial era, which later metamorphosed into the Igbomina/Ekiti division. In 1976 it was named Irepodun Local Government. Irepodun Local Government 
is divided into eleven political wards and a landmass of 1, 095 square kilometers. It is endowed with savannah/rain forest vegetation on a plain terrain with patches of river/streams to serve as verdant for early crops and animals grazing. The people of the Study area are predominantly farmers and they engage in petty and large scale trading.

\section{Study population and sampling procedure}

The population for the study comprised some selected childbearing women involved in agricultural activities in Irepodun Local Government Area of Kwara State. Simple random sampling were used to select four wards out of the eleven wards in the LGA based on the involvement of childbearing women in agricultural activities in the area namely: Omu-Aran 11, Ajase-Ipo II, Esie, and Oko. In each of the four wards thirty (30) respondents were selected using simple random sampling technique to give rise to 120 respondents for the distribution of questionnaire. Hence, a total of one hundred and twenty (120) respondents were used as sample size.

\section{Data analysis}

All the data was analyzed manually using SPSS package. Descriptive statistical techniques such as percentage and frequencies were used. The Pearson Product Moment Correlation (PPMC) was used to test the hypotheses.

\section{RESULTS AND DISCUSSION}

\section{Socio-economic characteristics of childbearing women involved in agricultural activities}

The frequency and percentage distribution of the socio-economic characteristic data of the respondents were determined. Socio-economic characteristics included: Age, marital status, how long respondents has lived in the village, farming experience and education level. The result is shown in table 1 Table 1 shows that majority of the respondents (76.7\%) fall within the age range of $26-45$ years. This result implied that majority were youth. These categories of people are still at their prime, economically active and thus energetic to undertake most agricultural activities for livelihood and sustenance. Majority $(80.5 \%)$ of the respondents are married. Table 1 revealed that $74.3 \%$ of the respondents have been farming for the past twenty years. This implied that majority of the respondents have been exposed to farming activities before marriage. $14.4 \%$ had primary education, $18.6 \%$ had secondary education, $4.2 \%$ had ordinary National Diploma, $22.9 \%$ had National certificate of Education, $2.5 \%$ of respondents had Higher National Diploma while $10.2 \%$ had Bachelor of Science certificate. This implied that majority $(72.8 \%)$ of the respondents were literate. 
Produced with a Trial Version of PDF Annotator - www.PDFAnnotator.com

Table 1: Distribution of the respondents by their socio economic characteristics

\begin{tabular}{llll}
\hline & Variables & Frequencies & Percentages \\
\hline (a) & Age & & \\
(i) & 20-25 years & 8 & 6.7 \\
(ii) & 26-35 years & 41 & 34.5 \\
(iii) & 36-45 years & 50 & 42.2 \\
(iv) & 46 and above & 20 & 16.6 \\
& & & \\
(b) & Marital Status & & \\
(i) & Married & 95 & 80.5 \\
(ii) & Widowed & 15 & 12.7 \\
(iii) & Divorced & 3 & 2.5 \\
(iv) & Single parent & 5 & 4.2 \\
& & & \\
(c) & Farming Experience & & \\
& 1-10 years & 42 & 35.4 \\
& 11-20 years & 46 & 38.9 \\
& 21-30 years & 18 & 15.1 \\
& Above 30 years & 5 & \\
& High Education level & & \\
(d) & No formal education & 30 & 25.4 \\
(i) & Primary education & 17 & 14.4 \\
(ii) & Secondary education & 22 & 4.2 \\
(iii) & OND & 5 & 22.9 \\
(iv) & NCE & 27 & 2.5 \\
(v) & HND & 3 & 10.2 \\
(vi) & B.Sc & 12 & \\
(vii) & & &
\end{tabular}

Source: Author, (2014)

Primary and secondary occupation of childbearing women involved in agricultural activities

Table 2: shows that $94.9 \%$ of the respondents are engaged in farming, either as their primary and secondary occupation. Also, the result shows that the respondents engage in more than one income generating activities to augment income received from agricultural activities. 
Produced with a Trial Version of PDF Annotator - www.PDFAnnotator.com

Table 2: Distribution of respondents according to their primary and secondary occupations

\begin{tabular}{llll}
\hline & Occupation & Frequencies & Percentages \\
\hline (a) & Farming & & \\
(i) & Secondary & 63 & 53.4 \\
(ii) & Primary & 49 & 41.0 \\
(b) & Trading & & \\
(i) & Primary & 27 & 22.9 \\
(ii) & Secondary & 52 & 44.0 \\
(c) & Artisan & & \\
(i) & Primary & 6 & 5.1 \\
(ii) & Secondary & 3 & 2.5 \\
(d) & Civil Service & & \\
(i) & Primary & 33 & \\
(ii) & Secondary & 10 & 27.1 \\
& & &
\end{tabular}

Source: Author, (2009)

\section{Agricultural activities practiced by childbearing women}

Table 3 indicates that $81.4 \%$ and $83.1 \%$ of the respondents were actively involved in harvesting and processing respectively, while $70.3 \%$ and $69.5 \%$ are engaged in planting and marketing. Also, $59.3 \%$ and $44.1 \%$ engage in weeding and land preparation, $37.3 \%$ and $33.9 \%$ engage in transplanting, fertilizer application and transportation of agricultural produce. This shows that majority of the respondents engage actively in harvesting and processing. This agrees with the findings of (Olawepo \& Fatulu, 2012) that women engage more in harvesting and processing of farm produce.

Table 3: Distribution of the respondents based on their involvement in agricultural activities

\begin{tabular}{llll}
\hline & Agricultural Activities & Frequency & Percentage \\
\hline (a) & Land preparation & 52 & 44.1 \\
(b) & Planting & 83 & 70.3 \\
(c) & Transplanting & 44 & 37.3 \\
(d) & Weeding & 70 & 59.3 \\
(e) & Fertilizer application & 40 & 33.9 \\
(f) & Harvesting & 96 & 81.4 \\
(g) & Processing & 98 & 83.1 \\
(h) & Marketing of Agric Produce & 82 & 69.5 \\
(i) & Transportation of Agric & 44 & 37.3
\end{tabular}

Source: Author, (2009)

\section{Agricultural activities that childbearing affected}

Table 4: shows that $72.0 \%$ of agricultural activities (weeding) were affected during childbearing, $70.3 \%$ during harvesting and processing, $71.2 \%$ during planting, $67.8 \%$ and $60.3 \%$ of agricultural activities was 
affected during childbearing. This shows that majority of agricultural activities are affected during childbearing. This is due to discomfort during pregnancy that limits the participation of the respondents in agricultural activities.

Table 4: Distribution of the respondents based on the agricultural activities that childbearing affected

\begin{tabular}{llll}
\hline & Agricultural Activities & Frequency & Percentage \\
\hline (a) & Land preparation & 80 & 67.8 \\
(b) & Planting & 84 & 71.2 \\
(c) & Transplanting & 77 & 65.3 \\
(d) & Weeding & 85 & 72.0 \\
(e) & Fertilizer Application & 71 & 60.2 \\
(f) & Harvesting & 83 & 70.3 \\
(g) & Processing & 83 & 70.3 \\
(h) & Marketing Agric produce & 79 & 66.9 \\
(i) & Transportation of Agric produce & 76 & 64.4 \\
\hline
\end{tabular}

Source: Author, (2009)

Effects of childbearing on the income of women involved in agricultural activities

Table 5 indicates that $72.0 \%$ of the respondents are participating in informal saving and credit group.63.8 $\%$ of the respondents contribute below $\$ 200$ equivalent to $\$ 1.5$ and $36.2 \%$ contribute $\$ 450$ equivalent to $\$ 2.5$ and above. Majority of the respondents contribute on daily basis and childbearing affects $42.4 \%$ of the respondent income while $57.6 \%$ are not affected by childbearing, since respondent have different source of generating income.

Table 5: Distribution of the respondent based on the effects of childbearing on their income

\begin{tabular}{lll}
\hline \multicolumn{1}{c}{ Frequency } & Percentage \\
\hline $\begin{array}{l}\text { Participation in informal } \\
\text { saving and credit group }\end{array}$ & & \\
Yes & 85 & 72.0 \\
No & 33 & 28.0 \\
Contribution on daily basis & & \\
Below 200 & 75 & 63.8 \\
450 above & 43 & 36.2 \\
Days in a week contribute & & \\
1-7 & 101 & 85.6 \\
No & 17 & 14.4 \\
Childbearing affect income & & \\
Yes & 50 & 42.4 \\
No & 68 & 57.6 \\
\hline Source: Author, (2009) & &
\end{tabular}

Source: Author, (2009)

\section{CONCLUSION AND RECOMMENDATIONS}

It has been revealed that agricultural activities practised by the childbearing women were affected during childbearing. This might be due to the rigours associated with subsistence agricultural practices which is the major farming system in the study area and the stress attached to childbearing. However, the result shows that rural women engage in more than one income generating activities to augment income received from agricultural activities. 
Therefore, women involved in agricultural activities should be given appropriate types of technology to cater for the labour intensive agricultural activities. Also, efforts should be made to reduce drudgery of domestic chores with the use of labour saving devices that save time and energy at home this will help women to participate more in agricultural activities during childbearing. Childbearing women are encouraged to join or form cooperative society in order to source funds from the government, NGOs, as well as access credit facilities from financial institutions to boost their involvement in agricultural activities.

\section{REFERENCES}

Michael Baksh, Charlotte G. Neumann, Michael Paolisso, Richard M. Trostle and A. A. J. Jansen. (1994): The Influence of reproductive status on rural Kenya Women's time use. Social science Medicine 39(3): 345-354

Chatterjee, M. (1991): Towards better health for Indian women. World Bank, South Asia Country Department Washington D.C.

Dilrukshi H.G., Russell .F. \& Karim M. M. (2013). Home gardens: a promising approach to enhance household food security and wellbeing, Agriculture \& Food Security, 2(8), 1-13.

Doss. C.R. (1999): Twenty five years of research on women farmers in Africa: Lessons and implication for agricultural research institutions; CIMMTT Economics program paper No 99-2 Mexico.

Irepodun Local Government, Area Kwara State www.kwarastate.gov.ng//repodun-Loca, http:www.kwarastate.gov.ng January, 2009.

Jean Pierre M.M. (2012): Gender Issues in Agriculture and Rural Employment in Wenchuan: The Place of Women, International Journal of Humanities and Social Science, 2(18), 23-28.

Odefadehan O. (1999): "Effect of Women Farmer Reproductive Roles on their Agricultural and Social Activities". Unpublished B.Sc Project in Department of Agricultural Extension and Rural Development, University of Ibadan, p50.

Okeowo, T. A. and Olujide, M. G. (2014): Attitude, Knowledge and Utilization of Family Planning Methods Among Rural Women in Ogun State, Nigeria, Agrosearch Volume 14(1):39-53

Olawepo .R. A. \& Bola F. (2012). Rural Women Farmers and Food Productivity in Nigeria: An Example from Ekiti Kwara, Nigeria, Asian Social Science, 8(10), 108-117.

Osondu, C. K. (2014): Determinants of Decision for Non-Farm Entrepreneurship by Women Farmers in Ikwuano LGA, Abia State, Agrosearch Volume 14(2):154-167.

Population Reports (1997) Number 10, 12, Baltimore, John Hopkins School of public health population information program. Pp 5

Ramesh H. P. (2013): An Empirical Study of Status of Women Agricultural Labour in India, India Journal of Research, 2(7), 45-46.

World Bank (1996): Toolkit on Gender and Agriculture; Working draft. Gender Analysis \& Policy Group, Poverty \& Social policy department, Washington, D.C. Duplicated.

Yusuf T. M. and Adenegan K. O. (2008 \& 2009): Technical Efficiency among Women Farmers in Kwara State: Data Envelopment Analysis Approach, Agrosearch 10 No. $1 \& 231$ - 45 